\title{
Prevalence of central obesity in a large sample of adolescents from public schools in Recife, Brazil
}

\author{
Prevalência de obesidade central em grande amostra de \\ adolescentes de escolas públicas em Recife, Brasil
}

Luiz H. M. Griz', Maíra Viégas², Mauro Barros³ ${ }^{3}$ Adriana L. Griz',

Eduardo Freese ${ }^{5}$, Francisco Bandeira'

\begin{abstract}
Objective:To determine the prevalence and association of central obesity (CO) and hypertension and its associations with alcohol intake, smoking and physical activity in adolescents. Subjects and methods: Cross sectional study in 1,824 students from 29 public schools in Recife. Results: $89.6 \%$ were normal weight, $6.7 \%$ overweight and $3.7 \%$ obese; $77.2 \%$ were normotensive, $5.9 \%$ prehypertensive and $16.9 \%$ hypertensive; CO was $10.2 \%$ when the $90^{\text {th }}$ percentile was used as cutoff and $25.2 \%$ when the $75^{\text {th }}$ percentile was used. There was a higher likelihood of central obesity among students aged 18 to 20 years, smoking and alcohol intake. The probability of hypertension increases if the subject is male, has a waist circumference (WC) $\geq 90, W C \geq 75$ and does not practice physical activity. Conclusions: A high prevalence of $\mathrm{CO}$ and hypertension was found in adolescents. $\mathrm{CO}$ was more frequent in students aged 18 to 20 years, smokers and with alcohol intake and hypertension was associated with male, $\mathrm{CO}$ and no physical activity. Arq Bras Endocrinol Metab. 2010;54(7):607-11
\end{abstract}

\section{Keywords}

Central Obesity; Adolescent Health; Alcohol; Blood Pressure; Physical Activity; Smoking

\section{RESUMO}

Objetivo: Determinar a prevalência e a associação de obesidade central (CO) e hipertensão e suas associações com consumo de álcool, fumo e atividade física em adolescentes. Sujeitos e métodos: Estudo de corte transversal em 1.824 estudantes de 29 escolas públicas em Recife. Resultadlos: $89,6 \%$ com peso normal, $6,7 \%$ sobrepeso e $3,7 \%$ obesidade; $77,2 \%$ normotensos, $5,9 \%$ pré-hipertensos e 16,9\% hipertensos; $10,2 \%$ de CO quando utilizado percentil 90 como ponto de corte e de $25,2 \%$ quando utilizado percentil 75 . Houve maior probabilidade de $\mathrm{CO}$ entre os estudantes com 18 a 20 anos, fumantes e consumo de álcool. A probabilidade de hipertensão aumenta nos homens, com WC (waist circumference) $\geq 90, W C \geq 75$ e sem atividade física. Conclusões: Elevada prevalência de $\mathrm{CO}$ e hipertensão foi encontrada em adolescentes. $\mathrm{CO}$ foi mais frequente nos estudantes com 18 a 20 anos, fumantes, e consumo de álcool e hipertensão foram associados com sexo masculino, CO e ausência de atividade física. Arq Bras Endocrinol Metab. 2010;54(7):607-11

Descritores

Obesidade Central; Saúde dos Adolescentes; Álcool; Pressão Arterial; Atividade Física; Fumo
1 Postgraduate Program in Hebiatrics, Medical and Dental Schools, Department of Endocrinology and Diabetes Universidade de Pernambuco (UPE), Recife, PE, Brazil

${ }_{2}^{2}$ Postgraduate Program in Health Science, Medical and Dental School, Department of Endocrinology and Diabetes, UPE, Recife, PE, Brazil ${ }^{3}$ Postgraduate Program in

Hebiatrics, UPE, Recife, PE, Brazil ${ }^{4}$ Medical Residency in Obstetrics and Gynecology, Instituto de Medicina Integral Prof. Fernando Figueira, Recife, PE, Brazil

${ }^{5}$ Postgraduate Program in Public Health, Fundação Oswaldo Cruz, Recife, PE, Brazil

\section{Correspondence to:}

Luiz H. M. Griz

Estrada das Ubaias, 332/302 52061-080 - Recife, PE, Brazil luizgriz@globo.com

Received on Mar/4/2010 Accepted on Sept/27/2010

\section{INTRODUCTION}

Central obesity is a major clinical and public health $\checkmark$ issue. There is evidence that central obesity is more strongly correlated with metabolic risk factors than with a high body mass index (BMI). A number of studies have shown that central obesity is an independent risk factor for type 2 diabetes mellitus, dyslipidemia, systemic arterial hypertension and coronary artery disease $(1,2)$. The risk of cardiovascular death, myocardial infarction, and all-cause death increases in parallel with waist circumference (WC) (3).

Two patterns of obesity are recognized: upper body obesity and lower body obesity. Individuals with the former are more susceptible to metabolic syndrome. 
The Bogalusa Heart Study showed that the distribution of central fat determined by WC at the ages of 5 to 17 years was associated with abnormal concentrations of triglycerides, LDL cholesterol, HDL cholesterol and insulin $(4,5)$.

A number of methods have been employed in the assessment of the distribution of regional fat, such as computed tomography and magnetic resonance imaging. Anthropometric measurements such as WC have been used as a simple and accurate method for assessing in adults and children the presence of central obesity (6-10). The best way to calculate central obesity in clinical practice is by measuring WC (11).

Cutoffs for defining the term central obesity are arbitrary. The National Cholesterol Education Program's Adult Treatment Panel III (NCEP ATP IIII) (12) has applied the term when WC is equal to or greater than $102 \mathrm{~cm}$ for men and $88 \mathrm{~cm}$ for women, and has employed the $\geq 90^{\text {th }}$ percentile of WC for defining central obesity in children and adolescents. The International Diabetes Federation (IDF) has used $94 \mathrm{~cm}$ for men and $80 \mathrm{~cm}$ for women in Europeans (13).

There are few population data in the literature regarding central obesity in adolescents and what abdominal circumference cutoff should be employed in the diagnosis of metabolic syndrome. Studies are therefore required in this age group to permit the identification of which adolescents are at risk.

\section{SUBJECTS AND METHODS}

A cross-sectional study was planned for the purpose of determining the prevalence of central obesity and hypertension in young people aged from 14 to 20 years, in secondary education in the public schools of Recife and its metropolitan region, and their relationship with living habits and blood pressure (BP).

Data was collected by means of the Global School-based Student Health Survey recommended by the World Health Organization for the purpose of assessing exposure to behaviors involving a risk to health in adolescents. After the questionnaire was applied, BP measurements and the anthropometric assessment (weight, height and WC) were performed. All the adolescents were examined by physicians, nurses and medical students specifically trained for this purpose by physicians involved in this project.

This study was approved by the Ethics in Research Committee of Agamenon Magalhães Hospital, in Reci- fe, Pernambuco, Brazil. Legal representatives gave their consent for the subject to take part in the study by signing the informed consent form.

A mercury column sphygmometer with an appropriately sized cuff, certified by INMETRO, the Brazilian Institute of Metrology, was used for measuring BP in the sitting position, two measurements were made with a 1 - to 2 -minute interval between them.

Hypertension in adolescents was defined as systolic or diastolic BP in the $\geq 95^{\text {th }}$ percentile for sex, age 14-17 years and height, verified on two occasions. Prehypertension was defined as systolic or diastolic pressure in the $>90^{\text {th }}$ and $<90^{\text {th }}$ percentiles, respectively, and normal BP as systolic or diastolic pressure in the $<90^{\text {th }}$ percentile $(14)$. For the measurements of $\mathrm{BP}$ in the individuals in the 18-20 years age group the methodological recommendations of the Seventh Report of the Joint National Committee on Prevention, Detection, Evaluation and Treatment of High Blood Pressure (JNC 7) Guidelines from the National Heart, Lung and Blood Institute were followed (15).

Weight was measured using calibrated digital scales. Height was measured with a wall-mounted stadiometer fitted with a graduated cursor with centimeter accuracy. The $\mathrm{k} / \mathrm{m}^{2}$ ratio was used to calculate BMI. No obese adolescents were defined as having a BMI lower than the $85^{\text {th }}$ percentile, overweight and obese adolescents were defined as a BMI in the $85^{\text {th }}$ to $94^{\text {th }}$ percentiles and the $95^{\text {th }}$ percentile or higher, respectively, according to the Centers for Disease Control and Prevention growth charts for US children.

WC was measured using an anthropometric tape at the level of the umbilicus and the practice of physical activity was recorded when it took place for a period of 60 minutes at least three times per week (16).

The Tanner Scale was not used for maturity because most subjects were already past puberty.

Descriptive statistics are expressed as mean \pm standard deviation or percentage. All analyses were conducted using the SPSS software (Statistical Package for Social Sciences), version 15. Differences between groups were analyzed using the chi-square test. The Odds Ratio (OR) and confidence intervals (95\% CI) were obtained in the association between the independent variables with $75^{\text {th }}$ percentile $\mathrm{WC}, 90^{\text {th }}$ percentile WC and BP. Multiple regression was performed to determine the influence of independent variables on $75^{\text {th }}$ percentile $\mathrm{WC}, 90^{\text {th }}$ percentile $\mathrm{WC}$ and hypertension 
by Backward selection. Evaluation of the sensitivity and specificity of BP according to percentiles of WC was performed. Statistical significance was considered when $\mathrm{p} \leq 0.05$.

\section{RESULTS}

The characteristics of the study patients are shown in table 1. The pupils were classified in two subgroups: those with a WC in the $\leq 10^{\text {th }}$ or $\geq 90^{\text {th }}$ percentiles and those with a WC in the $\leq 25^{\text {th }}$ or $\geq 75^{\text {th }}$ percentiles. Based on these subgroups an association was made with alcohol intake, smoking, hypertension and the practice of physical activity.

Table 1. General characteristics of 1,825 studies from 29 public schools in Recife

\begin{tabular}{|c|c|}
\hline Variable & Results \\
\hline \multicolumn{2}{|l|}{ Age (years): n (\%) } \\
\hline $14-15$ & $330(18.1)$ \\
\hline $16-17$ & $806(44.2)$ \\
\hline $18-20$ & $689(37.7)$ \\
\hline Sex: female: n (\%) & $1110(60.8)$ \\
\hline \multicolumn{2}{|l|}{ BMI: n (\%) } \\
\hline Normal & $1635(89.6)$ \\
\hline Overweight & $122(6.7)$ \\
\hline Obese & $68(3.7)$ \\
\hline Alcohol intake: n (\%) & $548(30.0)$ \\
\hline Smoking: n (\%) & $190(10.4)$ \\
\hline Lack of physical activity: $n$ (\%) & $777(42.4)$ \\
\hline WC $\geq$ P75: n (\%) & $460(25.2)$ \\
\hline WC $\geq$ P80: n (\%) & $375(20.5)$ \\
\hline WC $\geq$ P85: n (\%) & $274(15.0)$ \\
\hline WC $\geq$ P90: n (\%) & $186(10.2)$ \\
\hline WC $\geq$ P95: n (\%) & $91(5.0)$ \\
\hline \multicolumn{2}{|l|}{ Blood pressure: $n(\%)$} \\
\hline Normotensive & $1410(77.2)$ \\
\hline Prehypertensive & $107(5.9)$ \\
\hline Hypertensive & $308(16.9)$ \\
\hline Age (years): mean \pm STD & $17.05 \pm 1.59$ \\
\hline
\end{tabular}

BMI: body mass index; WC: waist circunference.

With regard to BMI, $89.6 \%$ were of normal weight, $6.7 \%$ overweight and $3.7 \%$ obese. Regarding BP, $77.2 \%$ were normotensive, $5.9 \%$ prehypertensive and $16.9 \%$ hypertensive. The mean BMI was $21.14 \mathrm{~kg} / \mathrm{m}^{2} \pm 3.55$ $\mathrm{kg} / \mathrm{m}^{2}$, and the mean systolic and diastolic pressures were $115.75 \pm 14.12$ and $74.23 \pm 10.01 \mathrm{mmHg}$, respectively.

The prevalence of central obesity using the $\geq 90^{\text {th }}$ percentile of WC was $10.2 \%$ and using the $\geq 75^{\text {th }}$ percentile was $25.2 \%$.

When analyzing the $\mathrm{WC} \geq 90$, according to the risk factors, there was a higher likelihood of central obesity among students aged 18 to 20 years $(\mathrm{p}<0.001)$ and smokers $(\mathrm{p}=0.0032)$ (Table 2$)$. While for the occurrence of $\mathrm{WC} \geq 75$ the probability of a student presenting central obesity is higher among students aged 18 to 20 years $(\mathrm{p}<0.001)$ and alcohol intake $(\mathrm{p}=0.092)$ (Table 2).

Table 2. Logistic regression analysis for the occurrence of $W C \geq 90$ and WC $\geq 75$ in students from public schools in Recife

\begin{tabular}{|c|c|c|c|}
\hline Variable & OR (95\% CI) & $\begin{array}{c}\text { OR (95\% Cl) } \\
\text { adjusted }\end{array}$ & p \\
\hline \multicolumn{4}{|l|}{$W C \geq 90$} \\
\hline & & & $p<0.001^{\star}$ \\
\hline Age (years) & & & $p<0.001^{*}$ \\
\hline 14 a 15 & 1.00 & 1.00 & \\
\hline 16 a 17 & $0.70(0.45$ a 1.09$)$ & 0.68 (0.44 a 1.07) & $p=0.096$ \\
\hline 18 a 20 & 1.44 (0.95 a 2.19$)$ & 1.38 (0.91 a 2.11) & $p=0.135$ \\
\hline \multicolumn{4}{|l|}{ Smoking } \\
\hline Yes & 1.70 (1.11 a 2.60$)$ & 1.61 (1.04 a 2.48) & $p=0.032^{\star}$ \\
\hline No & 1.00 & 1.00 & \\
\hline \multicolumn{4}{|l|}{$W C \geq 75$} \\
\hline & & & $p<0.001^{*}$ \\
\hline Age (years) & & & $p<0.001^{\star}$ \\
\hline 14 a 15 & 1.00 & 1.00 & \\
\hline 16 a 17 & $0.99(0.72$ a 1.36$)$ & 0.97 (0.70 a 1.34) & $p=0.853$ \\
\hline 18 a 20 & 2.06 (1.51 a 2.81$)$ & 1.98 (1.45 a 2.72) & $p<0.001^{*}$ \\
\hline \multicolumn{4}{|c|}{ Alcohol intake } \\
\hline Sim & $1.26(1.02$ a 1.56$)$ & 1.22 (0.97 a 1.53) & $p=0.092$ \\
\hline Não & 1.00 & 1.00 & \\
\hline
\end{tabular}

$\left({ }^{\star}\right)$ : statistical significance $5.0 \%$.

After logistic regression adjustment, it was observed that the likelihood of a student showing hypertension increases if male $(\mathrm{p}<0.001), \mathrm{WC} \geq 90(\mathrm{p}<0.001)$ and no physical activity $(\mathrm{p}<0.001)$ (Table 3$)$. When the logistic regression was analyzed with $\mathrm{WC} \geq 75$, the probability of a student having hypertension was higher in male $(\mathrm{p}<0.001), \mathrm{WC} \geq 75(\mathrm{p}<0.001)$ and no physical activity $(\mathrm{p}=0.001)$ (Table 3$)$.

Results of the evaluation of sensitivity and specificity to hypertension according to percentiles of WC in male and female are shown in table 4. 
Table 3. Logistic regression analysis for the occurrence of hypertension, using $W C \geq 90$ and $W C \geq 75$, in students from public schools in Recife

\begin{tabular}{|c|c|c|c|}
\hline \multicolumn{4}{|l|}{ WC $\geq 90$} \\
\hline Variable & OR (95\% Cl) & OR (95\% CI) adjusted & $\mathbf{p}$ \\
\hline & & & $p<0.001^{*}$ \\
\hline \multicolumn{4}{|l|}{ Sex } \\
\hline Male & 2.20 (1.72 a 2.82) & 2.35 (1.82 a 3.04$)$ & $p<0.001^{*}$ \\
\hline Female & 1.00 & 1.00 & \\
\hline \multicolumn{4}{|c|}{ Percentile of $W C \geq 90$} \\
\hline$\geq 90$ & 3.36 (2.42 a 4.66$)$ & 2.48 (2.49 a 4.87) & $p<0.001^{*}$ \\
\hline$<90$ & 1.00 & 1.00 & \\
\hline \multicolumn{4}{|c|}{ Physical activity } \\
\hline No & 1.21 (0.94 a 1.54) & 1.37 (1.06 a 1.78) & $p=0.015^{*}$ \\
\hline Yes & 1.00 & 1.00 & \\
\hline \multicolumn{4}{|l|}{ WC $\geq 75$} \\
\hline & & & $p<0.001^{*}$ \\
\hline \multicolumn{4}{|l|}{ Sex } \\
\hline Male & 2.20 (1.72 a 2.82) & 2.35 (1.82 a 3.03$)$ & $p<0.001^{*}$ \\
\hline Female & 1.00 & 1.00 & \\
\hline \multicolumn{4}{|c|}{ Percentile of $W C \geq 75$} \\
\hline$\geq 75$ & 2.41 (1.86 a 3.12$)$ & 2.28 (1.91 a 3.23$)$ & $p<0.001^{*}$ \\
\hline$<75$ & 1.00 & 1.00 & \\
\hline \multicolumn{4}{|c|}{ Physical activity } \\
\hline No & $1.21(0.94$ a 1.54$)$ & $1.40(1.09$ a 1.81$)$ & $p=0.010^{*}$ \\
\hline Yes & 1.00 & 1.00 & \\
\hline
\end{tabular}

$\left(^{\star}\right)$ : statistical significance: $5.0 \%$.

Table 4. Evaluation of sensitivity and specificity to hypertension according to percentiles of WC

\begin{tabular}{|c|c|c|c|c|c|c|}
\hline \multirow{2}{*}{ WC percentile } & \multicolumn{3}{|c|}{ Sensitivity (S\%) } & \multicolumn{3}{|c|}{ Specificity (E\%) } \\
\hline & Students (n) & Hipertensives (n) & $\mathbf{S}$ & Students (n) & Hypertensives (n) & $\mathbf{E}$ \\
\hline$\geq P 75$ & 460 & 125 & 27.2 & 1,365 & 1,182 & 86.6 \\
\hline$\geq P 80$ & 375 & 111 & 29.6 & 1,450 & 1,253 & 86.4 \\
\hline$\geq P 85$ & 274 & 91 & 33.2 & 1,551 & 1,334 & 86.0 \\
\hline$\geq P 90$ & 186 & 68 & 36.6 & 1,639 & 1,399 & 85.4 \\
\hline$\geq$ P95 & 91 & 42 & 46.2 & 1,734 & 1,468 & 84.7 \\
\hline
\end{tabular}

\section{DISCUSSION}

In this study, we presented data on central obesity in the adolescent population from public schools in Brazil and the association between WC and BP and risk factors. The prevalence of $\mathrm{BP}$ in our subjects was lower compared with other studies (17), while the prevalence of obesity was lower compared with private schools (18).

The NCEP ATP III has defined central obesity in children and adolescents as a WC $>$ the $90^{\text {th }}$ percentile. Although the IDF has not proposed any change in the WC percentile that should be used in diagnosis of the metabolic syndrome, it has been using a lower cutoff of WC for adults. In addition to using a lower cutoff, the IDF, unlike the NCEP ATP III, considers that a high WC is essential for diagnosing metabolic syndrome.

A study carried out in the United States of America (19) that included 639 Americans of Japanese descent found an optimum WC cutoff of $80.8 \mathrm{~cm}$ in women under the age of 56 years and over and of $89.0 \mathrm{~cm}$ in those over 56 , the corresponding figures for men under 
and over 56 being $90.0 \mathrm{~cm}$ and $87.1 \mathrm{~cm}$, respectively. These results demonstrate that WC cutoffs should be specified according to ethnic group, age and gender. The present study demonstrated that male students aged 18 to 20 years have a higher probability of having central obesity by $\geq 75^{\text {th }} \mathrm{WC}$ and $\geq 90^{\text {th }} \mathrm{WC}$.

The position of the IDF and the results of the aforementioned study in Americans of Japanese descent reinforce the need to find a cutoff for each population and gender and enhance the results of the present study as we have found an association between hypertension and $\geq 75^{\text {th }}$ percentile $\mathrm{WC}$ and $\geq 90^{\text {th }}$ percentile WC. Therefore, hypertension is associated with central obesity when lower cutoff for WC adolescents was used than that proposed by NCEP ATP III. These results are important because hypertension is an important factor for cardiovascular risk and is included as a component of the metabolic syndrome by all the organizations that have issued guidelines on this syndrome. Data from the National Health and Nutrition Examination Survey (NHANES) III demonstrate that WC correlates more closely than BMI with hypertension.

The data demonstrated that central obesity is correlated with lifestyle. WC in the $\geq 75^{\text {th }}$ and $\geq 90^{\text {th }}$ percentiles was found to be associated with alcohol intake and smoking. The lack of physical activity is one of the cardiovascular risk factors (20). All the components of the metabolic syndrome improved with exercise, including a decrease in insulin resistance, an improvement in the lipid profile (reduction in LDL cholesterol and triglycerides and increase in HDL cholesterol) and a fall in BP levels. The present study found an association between hypertension and lack of physical activity when we use both $75^{\text {th }}$ and $90^{\text {th }}$ percentiles to define central obesity. The major benefit derived from physical activity is the reduction of weight in obese individuals.

In conclusion, we found a high prevalence of central obesity and hypertension in adolescents attending public schools, as well as an association between WC, lifestyle and BP.

Disclosure: no potential conflict of interest relevant to this article was reported.

\section{REFERENCES}

1. Larsson B, Svardsudd K, Welin L, et al. Abdominal adipose tissue distribution, obesity, and risk of cardiovascular disease and death: 13 years follow up of participants in the study of men born in 1993. Br Med J. 1984;288:1401-4.
2. Ducimetiere P, Richard J, Cambien F.The pattern of subcutaneous fat distribution in middle-aged men and the risk of coronary heart disease: the Paris Prospective Study. Int J Obes. 1986;10:299-40.

3. Dagenais GR, Yi Q, Mann JF, Bosch J, Pogue J, Yusuf S. Prognostic impact of body weight and abdominal obesity in women and men with cardiovascular disease. Am Heart J. 2005;149:54-60.

4. Freedman DS, Dietz WH, Srinivasan SR, et al. The relation of overweight to cardiovascular risk factors among children and adolescents: the Bogalusa Heart Study. Pediatrics. 1999;103:1175-82.

5. Freedman DS, Serdula MK, Srinivasan SR, et al. Relation of circumferences and skinfold thicknesses to lipid and insulin concentrations in children and adolescents: the Bogalusa Heart Study. Am J Clin Nutr. 1999;69:308-17.

6. Lean ME, Han TS, Morrison CE. Waist circumference as a measure for indication need for weight management. Br Med J. 1995;311:58-61.

7. Rankinen T, Kim SY, Pérusse L, Després JP, Bouchard C. The prediction of abdominal visceral fat level from body composition and anthropometry: ROC analysis. Int Obes Relat Metab Disord. 1999;23:801-9.

8. Lemieux S, Prud'Homme D, Bouchard C, et al. Sex differences in the relation of visceral adipose tissue accumulation to total body fatness. Am J Clin Nutr. 1993;58:463-7.

9. Goran MI, Allison DB, Poehlman ET. Issues relating to normalization of body fat content in men and women. Int J Obes Relat Disturb. 1995;19(S1):638-43.

10. Fox P, Peters D, Amstrong N, Sharpe P, Bell M. Abdominal fat deposition in 11-year-old children. Int $\mathrm{J}$ Obes Relat Metab Disord. 1993;17(S1):11-6.

11. Grundy SM, Hansen B, Smith JR, Cleeman JI, Kahn RA; American Heart Association; National Heart, Lung, and Blood Institute; American Diabetes Association. Clinical Management of Metabolic Syndrome: Report of the American Heart Association. Circulation. 2004;109:551-6.

12. National Cholesterol Education Program - NCEP. Expert Panel on Detection, Evaluation, and Treatment of High Blood Chlolesterol in adults (Adult treatment Panel III) final report. Circulation. 2002;109:5551-63.

13. Epidemiology Task Force Consensus Group. The metabolic syndrome - a new worldwide definition. Lancet. 2005;366:1059-62.

14. The Fourth Report on the diagnosis, evaluation and treatment of high blood pressure in children and adolescents. Pediatrics. 2004;114:555-76.

15. National Institutes of Health (NIH) Publications [internet database]. Bethesda: National Institutes of Health; 2003 [access on June 2006]. Publication No 03-5233. Avalaible at: http://www.nia.nih. gov/HealthInformation/Publications/

16. Center for Disease Control and Prevention. Avaiable at: www.cdc. gov/gshs. Access on: 9 Apr 2010.

17. Da Silva RCQ, Miranda WL, Chacra AR, Dib SA. Metabolic syndrome and insulin resistance in normal glucose tolerant Brazilian adolescents with family history of type 2 diabetes. Diabetes Care. 2005;28(3):716-8.

18. Balaban G, Silva GA. Prevalência de sobrepeso em crianças e adolescentes de uma escola da rede privada de Recife. J Pediatr (Porto Alegre). 2001;77(2):92-100.

19. Hayashi T, Boiko EJ, Mcneely MJ, Leonetti DL, Kahn SE, Fujimoto WY. Minimum waist and visceral fat values for identifying Japanese Americans at risk for the metabolic syndrome. Diabetes Care. 2007;30(1):120-7.

20. Fletcher GF, Balady G, Blair SN, Blumenthal J, Caspersen C, Chaitman B, et al. Statements on exercise: benefits and re commendations for physical activity programs for all Americans. A statement for health professionals by the Committee on Exercise and Cardiac Rehabilitation of the Council on Clinical Cardiology, American Heart Association. Circulation. 1996;94:857-62. 